\title{
7 \\ Witchcraft as an expression of female sexuality
}

That "a greater multitude of witches is found among the weaker sex of women than among men" was so obviously a fact to the authors of the Malleus that, despite scholastic custom, it was completely unnecessary to deduce arguments to the contrary. ${ }^{1}$ Witches, in their view, were entirely more likely to be women than men. The experience of the next two hundred years appeared to vindicate this judgment. Throughout most of central and western Europe, where witchcraft persecution was most intense, between 70 and 80 percent of convicted witches were women. ${ }^{2}$ Institoris and Sprenger's learned successors in the sixteenth and seventeenth centuries - demonologists and their skeptical opponents alike - concurred with their evaluation: to the well informed, witches were almost always women.

It is possible, however, that Institoris and Sprenger's own construction of witchcraft prejudiced the issue: were women singled out for persecution by later witch-hunters precisely because Institoris and Sprenger had already arbitrarily defined witches as women? Was, in Christina Larner's apt phrase, witch-hunting actually woman-hunting? ${ }^{3}$ Or are Institoris and Sprenger basically right - that without any learned coaching, people more often accused women of witchcraft than men? In other words, is the gender bias of texts like the Malleus descriptive or prescriptive in nature?

Many modern scholars incline toward the latter view, and look to medieval clerical misogyny, masculine anxieties about the changing social, economic, or familial roles of women, women's control over proscribed medicinal or magical activities, or changing notions of gender to explain why witches were women. ${ }^{4}$ Institoris and Sprenger, however, are adamant that their characterization of witches as predominately female is no more than an accurate description of reality: their own first-hand experience and the reliable testimony of trustworthy witnesses show this to be true. ${ }^{5}$ Though this claim of objectivity has often been dismissed by scholars, who point out that prior to the Malleus men were at least as often identified as witches in learned treatises 
as were women, it may have substantial validity. ${ }^{6}$ Notions of gender intersected the various constituent categories of witchcraft in different ways, and because different authors had quite different notions about what witchcraft was, their opinion of the probable gender of witches varied accordingly.

Some of the categories out of which late-medieval witchcraft evolved were more closely associated with women than others. There was, for example, universal agreement among clerics that women most generally held the beliefs condemned by the canon Episcopi. It was further agreed that not only did women believe that they rode at night in the company of fairies (or demons), but that the beings whom they followed were exclusively female as well. Not only were Diana, Herodias, Holda, and company all female, but so were their malign counterparts, the lamiae, strigae, unholdas, and other bloodsucking, night-flying hags that provided an archetype in legend and folklore for the witch in her most monstrous form. This archetype could also be actualized in the form of an accusation against real women. The sixth-century Pactus Legis Salicae orders that a stria who is proven to have eaten a man is liable to a fine of 8000 denarii. ${ }^{7}$ In later law codes, it was rather the belief in such creatures that was more often condemned, with women who were accused of being monstrous witches frequently entitled to compensation. The continuing presence of such laws testifies to the durability of the belief that certain women could be strigae in fact, as do similar entries in early-medieval penitentials and the later exempla of preachers, and this popular belief existed side by side with the educated, clerical position approved by the canon Episcopi. Women were thus liable to attack from two sides. As their beliefs became progressively more demonized, and as judicial and ecclesiastical authorities began to place more credence in charges that they committed real crimes, women associated with these beliefs became open to accusations of heresy, and, eventually, of witchcraft.

For theorists who based their model of witchcraft on such traditional beliefs, witches, logically, tended to be women. Thus, the witches of Girolamo Visconti and Ambrosius de Vignate were generally women. Likewise, Alphonso de Spina's witches are unmistakably female: he reported that demons deceived "cursed old women" ("vetulas maledictas") into thinking that they went by night to the Sabbat, and that vast numbers of such "perverse women" had overrun Dauphiné and Gascony, although many had already been convicted of heresy and burned. ${ }^{8}$

These women were not, however, accused of maleficium, but heresy: insofar as they complied with the devil's promptings, they were guilty of demonolatry, even if their crimes were committed while they slept. Worse still, such women did not renounce their imagined nocturnal crimes when they 
awoke, but reveled in their sin. So ran the usual argument. But although the heretical nature of their beliefs might appear clear, this itself raised another problem: the demography of heresy was well known, and heretical sects, unlike the company who flew with the bonae res, or even the legions of the superstitious, were not noticeably biased toward female members. The more reliant a definition of witchcraft was upon the model provided by diabolic heresy, the less could witchcraft be confined to women. Girolamo Visconti faced this problem when he turned to the question of whether his strigae and lamiae were guilty of heresy. Before he could assure his readers that witches were, indeed, heretics - regardless of the objective reality of their crimes and that, contrary to the canon Episcopi, men as well as women went to the ludus, he had also to admit - somewhat sheepishly - that women were certainly more numerous at these gatherings, and that "because there are more such women than men, there is more to say of them.".

Demonologists and witch-theorists who structured their notions of witchcraft more precisely around the familiar paradigms provided by heretical sects were more emphatic. Nicholas Jaquier's diabolic sect of fascinarii, for example, contained both men and women, with men usually taking their expected roles as leaders. This allowed him to use the gender specificity of the canon Episcopi to his advantage, and argue that the canon could not be applied legitimately to the modern sect of witches, because while it spoke of a delusion found solely in women, both sexes were found among the fascinarii. ${ }^{10}$ Similarly, the gender of witches was of no particular moment to the author of the Errores Gazariorum, who merely remarked that the heretics attempted to recruit members from both sexes into their sect, and that at their orgies both men and women were adequately represented. ${ }^{11}$ In LaVauderye de Lyonois en brief (c. 1460), the sex of the sectaries is not mentioned at all; instead, the author notes with care "that people of all ranks and conditions belong to this damnable sect." 12

Logically, where such heresy-based constructions of witchcraft were most widely accepted, women should not have been singled out for persecution. Susanna Burghartz has compared the witch-trials in Lucerne and nearby Lausanne during the fifteenth and sixteenth centuries, looking specifically for gender bias. ${ }^{13}$ In Lucerne, where witches were tried by the secular authorities, over 90 percent of those accused of witchcraft between 1398 and 1551 were women. Judges in this region had a quite rudimentary knowledge of contemporary demonology, and focused principally upon the concerns of the witnesses themselves, especially maleficium. In Lausanne, on the other hand, witchcraft prosecution was controlled by the episcopal inquisition, for whom heresy and demonolatry were major concerns, and only 38 percent of those 
prosecuted were women. Thus, a learned construction of witchcraft appears actually to have ameliorated the gender bias inherent in popular assessments of maleficium.

Unfortunately, the problem is seldom so clearly defined, since for both judges and scholarly authors an understanding of witchcraft was often derived from the assimilation of competing categories. While heresy may have been more or less gender neutral, superstition certainly was not: for centuries, superstition and magic had been conceived as particularly feminine vices, and for theorists who constructed witchcraft principally around notions of maleficium, this tradition informed witches' gender.

Clerical authors had for centuries been unanimous in their opinion that women were more prone to superstitious beliefs and observances of all types than were men. In the penitentials of the early Middle Ages, women were consistently singled out as the most likely practitioners of condemned magic and superstition. Burchard of Worms regularly identifies forbidden superstitious and pagan practices with allusions to "the vanities which women do" or to "what some women do at the instigation of the devil." Throughout the high Middle Ages, clerical exempla echoed this general perception. Stephen of Bourbon condemns women who make charms with the sacrament or with sacred things. ${ }^{15}$ The thirteenth-century Liber Exemplorum tells of evil and superstitious women who make a man of straw while one of their number is in labor, and dance and sing around this idol. ${ }^{16}$ Endless stories of this type were available, making the village wise woman, along with shrewish wives and grasping usurers, a stock character in Sunday homilies.

Like witches, these wise women combined a reputation for occult powers with a propensity to interfere in the sexual and marital affairs of their neighbors. Jacques de Vitry tells of a young man who was hopelessly in love with a girl who would have nothing to do with him. In desperation, the youth turned for help to a certain old woman, who concocted a clever plan. First, she told the would-be lover to pretend to be gravely ill. Then, she fed mustard seed to her little dog to make the animal shed tears, and brought it to the maiden in question, telling her that the animal had once been a woman who had allowed a suitor to die for the love of her, adding ominously that the girl had then been turned into a dog by magical spells, "which God permitted on account of her sin." ${ }^{\prime 17}$ To avoid such a fate, the girl accepted the young man as her lover. Foolish old women such as this, Jacques tells us, had no real occult power, but they used their reputations as sorceresses and their knowledge of popular superstitions to work extensive evil. They were, in his words, "the enemies of Christ, ministers of the devil, and the foes of chastity." ${ }^{18}$

Although greatly exaggerated and distorted, such tales offer a legitimate representation of the world as medieval preachers saw it. The use of various 
stereotypical characters in exempla was intended to denounce real and not imaginary sins, and if they were not perceived to have had a legitimate relationship with contemporary society, they would not have been effective. This is not, of course, to say that medieval women were more superstitious than men in any absolute sense, only that they were commonly perceived to be so.

The authorities of the late-medieval Church agreed that, by their very nature, women were more superstitious than men. John of Frankfurt, writing in 1412 , remarked that

women are less vigorous in reason and understanding than men, and this is why they are more readily held in the snare of superstitions and are less easily dissuaded from them. ${ }^{19}$

Jean Gerson argued that similar mental weaknesses made "old women, girls and boys, and the slow-witted more prone to observing and believing such superstitions." ${ }^{20}$ Nider in his Praeceptorium elaborated upon this theme, and gave what would become the three canonical reasons for women's inclination to superstitious practices. First, women were simply more credulous than men, and since false and erroneous faith was a principal aim of the devil, he mercilessly exploited this weakness. Second, women were especially vulnerable to diabolic assaults because their impressionable natures made them more apt than men to the influences and revelations of spiritual beings. Finally, because they had "slippery tongues," women were unable to conceal from their sisters what they had learned by their magic arts, and, since they were not strong, they were easily inclined to seek revenge though maleficium. ${ }^{21}$

Nider's concluding remark is especially relevant, because it links superstitious belief directly with the practice of black magic. Of course, as has already been pointed out, the practice of maleficium was a species of superstition, and insofar as women were more prone to superstition, it made sense to assume that they were also especially prone to witchcraft. Gerson was making just this point when he wrote that because of their propensity for superstitious practices, old women had earned their French epithet "old sorceresses."22 Nider, however, suggests that women who practice witchcraft are guilty of a specifically moral error rather than an intellectual one. Associating women with superstition, Nider combines ideas drawn from a somewhat different tradition in which women, specifically, were suspected of being maleficae.

Throughout the Middle Ages, women were often accused of malign sorcery. Clerical exempla make it clear that village wise women were sometimes thought guilty of more than just sharp practice. Although Jacques de Vitry (c. 1180-c. 1240) usually scoffs at the occult powers of old women, he also tells of certain maleficae mulieres who seemed to turn a woman into a mare, until the deception of the devil was revealed and undone through the prayers 
of a saint. ${ }^{23}$ Jacques does not tell the story in full, but in his source, the Vitae Patrum, the woman was bewitched because she had spurned an evil man's advances, who then had recourse to magic to gain his revenge. This is, then, almost the same story as Jacques's tale of the old woman and her weeping dog, but here the power of old wives is not trivial. Tellingly, Jacques made a significant adjustment to his text: in the original, the magician was a man; for Jacques, however, this kind of magic was typical of women.

Other sources, too, attributed harmful sorcery especially to women. As Nider observed, because women were thought less able than men to gratify their thirst for revenge through overt violence, they were widely believed to employ occult means. In his penitential, Burchard warned that some women, "filled with the discipline of Satan," would remove turf from the footprints of unsuspecting victims "and hope thereby to take away their health or life." ${ }^{24}$ In a canon devoted to the sins of women, the Anglo-Saxon penitential of Egbert also remarked upon the female propensity for magical harm, charging that

If a woman works witchcraft and enchantment and [uses] magical philters, she shall fast for twelve months . . If she kills anyone by her philters she shall fast for seven years. ${ }^{25}$

In the late twelfth century, Peter of Blois accused women of making wax and clay figurines either for the purposes of love magic or for straightforward revenge. ${ }^{26}$ Aragonese laws of the same century condemned to death women guilty of harming men or beasts through ligatures, herbs, or facticiosa. ${ }^{27}$ Late thirteenth-century Swedish law similarly stated that a woman who killed a man through maleficium should be burned. ${ }^{28}$ In short, although the sources are not unanimous, and although men were certainly thought able to work magic if so inclined, it seems, as Nider in effect argued, that the common association of women with superstitious practices in general, and their inability to exact revenge through other means, combined to make them especially liable to charges of practicing maleficium. ${ }^{29}$

Studies of sixteenth and seventeenth-century witch-beliefs support this conclusion. In his examination of witchcraft accusations in seventeenthcentury Yorkshire, J.A. Sharpe concludes that the witch embodied a peculiarly feminine kind of negative power, "the power to make trouble"; maleficium at the local level was a manifestation of tension and conflict centering on this perceived power of women. ${ }^{30}$ Clive Holmes agrees, and argues that in popular belief, "the mysterious powers that constituted witchcraft would normally be possessed by women." ${ }^{31}$ Christina Larner is similarly inclined to see the prosecution of female witches as simply the reflection of a widespread consensus that women especially work magical harm. ${ }^{32}$ Although medieval records do 
not permit the same sort of extensive investigation of local-level witchcraft belief through trial records and depositions that is possible for later periods, anecdotal evidence may suggest that similar patterns held true. Thus in Ghent during the 1370s, accusations of maleficium emerged out of women's quarrels, jealousies, and rumors, precisely as they are described in the Malleus. ${ }^{33}$ Since, moreover, there is no reason to assume that patterns of witch-belief changed dramatically on the local level after 1500, it is quite possible that accusations of harmful magic tended to cluster around women during the Middle Ages just as they did in later years. This is, at any rate, the position of the many latemedieval demonologists and witch-theorists who accepted without hesitation the proposition that women, in general, were more often superstitiosae et maleficae than men.

Maleficium was not, however, a clearly defined, homogeneous category, but an amalgamation of harmful conditions that could in some way be linked with particular superstitious practices (from the perspective of the learned observer), particularly meaningful events, or particularly motivated individuals (from the perspective of the victim). Some effects, motivations, and practices were more closely associated with the domain of women than were others. To take the most obvious example, love magic of various sorts was invariably recognized as the specific provenance of female magicians. Magic of this type acted principally to increase or diminish sexual passion and marital affection, or to cause sexual dysfunction, sterility or abortion. ${ }^{34}$ There were many practices associated with these kinds of maleficium, but ligatures, weaving, and binding magic were most common. ${ }^{35}$ For this reason, clerical authorities thought that magical operations of this sort were among the most common, and, because they seemed so obviously superstitious and diabolical, they provided clerics with a basic paradigm for "popular" magic. The constant insistence on the part of theologians that such magic was, indeed, diabolical cast women's magic in an increasingly sinister light from the thirteenth century onwards.

Moreover, because problems of impotence, loss of marital affection, and infertility remained widespread, reports and accusations of this type of magic intruded regularly into the pastoral experiences of the clergy. By the fifteenth century, among both witch-theorists like Institoris and Sprenger and clerics less intimately involved in the witch debates, love magic came to be seen not so much as a species of superstition, but as evidence of an overt and explicit pact with the devil. Gabriel Biel (d. 1496) was one of many clerics whose interest in maleficium was restricted principally to its practical effects upon marriage, but who nonetheless agreed with the witch-theorists that women did not work their spells through any power of their own, but only "through the help of demons whose pacts and sacraments they employ." 36 
Just as love magic was an area of undoubted female expertise, other kinds of sorcery were more often associated with men. Learned magic of various sorts provides the most obvious example of an almost entirely masculine occult domain. The Middle Ages recognized a whole range of magical operations for which literacy and extensive book learning were prerequisites. At one end of the spectrum was the scientia magica of Ficino and Giovanni Pico della Mirandola, an enormously complex and intellectually difficult attempt to understand God and his creation through ritual and meditation. ${ }^{37}$ At the other, there were the crude magical practices and recipes found in books of necromancy and compilations of miscellaneous sorcery. Between these two extremes was an extensive middle ground comprising alchemy, astrology and assorted divinatory practices, the manufacture of magical talismans and amulets, and the use of herbs, stones, and other materials in magical and quasi-magical ways. ${ }^{38}$ At various times, all of these practices were condemned by the Church, although with greatly varying degrees of severity, and never as consistently or intensely as were the characteristic magical practices of women. In many cases, learned magicians were able to mount sophisticated defenses of their procedures and acquit themselves of charges of superstition and idolatry. In others, licit practices were coupled with the suspect in a confusing melange that defied easy condemnation. Most of all, though, "book" magic was less often identified with maleficium than were other magical practices, and so there was never the same victim-driven impetus for persecution. Similarly, whereas love magic was a matter of practical daily concern for many clerics, learned magic was a problem principally of theoretical interest. Thus, the most typically masculine forms of magical practice remained largely insulated from the persecutions of the late Middle Ages, and were never successfully integrated into learned constructions of witchcraft.

Nonetheless, between these two clearly gendered poles of medieval magical practice, there were many kinds of magical operations, some of which were indifferently ascribed to men and women alike, and some of which were, at times, perceived to be more sex-specific. Despite his general claim that women were inherently inclined toward magic and superstition, Johann Nider was also careful to distinguish between the magic of male and female sorcerers. He writes that while it was a malefica or a maga who caused destructive rain to fall with her broom, it was the maleficus who made magical images from wax or lead. ${ }^{39}$ Similarly, while malefici could make imperfect animals after the manner of Pharaoh's magicians, with the help of demons, only women hurt children with their poisonous glances. ${ }^{40}$ To Nider, it would seem that harmful magic was much less the single, undifferentiated category that it became in the Malleus, but a more complicated system of categories specific to gender and culture. 
In Martin of Arles's examination of local superstition, he made similar distinctions between typically male and female magic. Following traditions laid down in antiquity, Martin used the masculine form of the words for witch, magician, and sorcerer, when speaking generically: maleficus, magus, incantator, praestigiosus, and so on. When he turned to specific kinds of magic, however, he chose the gender of his words very carefully. Male magicians, Martin tells us, practiced learned magic, image magic, astrology, and divination of all sorts. ${ }^{41}$ The evil eye and maleficium that impeded procreation, on the other hand, belonged to maleficae and vetulae sortilegae. ${ }^{42}$ Logically, when Martin looks at the traditions of the night-flying women commonly known as broxae, he refers only to "mulieres sortilegae et maleficae." ${ }^{\text {"3 }}$ Finally, he specifically mentions that the ranks of magicians who used various kinds of stones, herbs, woods, animals, songs, and rites to invoke demons to do their will included both malefici and maleficae in their number. ${ }^{44}$

Institoris and Sprenger's innovation was not their insistence that women were naturally prone to practice maleficium - in this they were simply following long-standing clerical traditions. Rather, it was their claim that harmful magic belonged exclusively to women that was new. If this assertion was granted, then the presence of maleficium indicated decisively the presence of a female witch. In the Malleus, the field of masculine magic is dramatically limited and male magicians are pointedly marginalized; magic is no longer seen as a range of practices, some of which might be more characteristic of men, some of women, and some equally prevalent among both sexes. Instead, it was the effects of magic that mattered most, and harmful magic, the magic most characteristic of witches, belonged to women. Men might be learned magicians, anomalous archer wizards, or witch-doctors and superstitiosi, but very seldom did they work the broad range of maleficium typical of witches.

The simplest explanation for this change is to accept, as Institoris and Sprenger claim, that it derives from their own experience as witch-hunters. Since their professional activities were restricted geographically to southern Germany and Austria, and since their investigations tended to focus upon charges of maleficium most often associated with women, it is not unreasonable to suppose that most of the accused witches whom they encountered were women. Nor was their conclusion some kind of inquisitorial idiosyncrasy. Their contemporary, Ulrich Molitor, though in other respects a man with quite different ideas about witchcraft, also assumed that witches were female as a matter of course: they were women driven to devote themselves to the devil "either because of desperation, or poverty, or the hatred of neighbors, or other temptations sent by the devil." ${ }^{\text {45 }}$ Although men could certainly work magic with the aid of the devil, Molitor tended to restrict masculine magical enterprises to comparatively benign activities such as fortune-telling: as a general 
rule, witches who worked maleficium were maleficae mulieres, while magi or malefici predicted the future. ${ }^{46}$

That witches were women was a conclusion that Institoris and Sprenger's contemporaries would not have found especially alarming - extreme, perhaps, but not so radical as to leave the pale of accepted clerical tradition. ${ }^{47}$ On the other hand, what the authors of the Malleus did with this observation, how they explained it, and how they made it integral to their understanding of witchcraft, was quite unusual indeed. To explain the phenomenon they assembled a formidable catalogue of authorities, ancient and modern, to testify to feminine weakness, sinfulness, and perfidy. ${ }^{48}$ After a polite enough nod to the glories of the Virgin, admitting that, just as an evil woman exceeds all others in iniquity, so a good woman is a model of righteousness, the authors begin to show how a propensity for witchcraft is the logical and necessary result of women's nature. To Nider's traditional explanation for women's inclination to superstitious beliefs, Institoris and Sprenger graft a veritable summa of latemedieval misogynist commonplaces. "Since women," they write, "are deficient in all strengths, as much of mind as of body, no wonder that they cause a great deal of witchcraft to be done to those who oppose them." ${ }^{, 49}$ Intellectually, women are childlike, so feeble-minded that they are of a completely different order from men. ${ }^{50}$ Their minds are warped, twisted like the rib from which Eve was first formed; and just as the first woman could not keep faith with God, so all women are faithless. This, the authors add, is shown by the very etymology of the word for "woman," "for it is said that femina is from $f e$ and minus because a woman always has and keeps less faith." weak memories, and from this defect "it is a natural vice in them to refuse to be governed, but to follow their impulses without any due reserve." 52 Their will, too, is warped, because they are inordinately passionate, more prone to violent love and hate, and so often turn to witchcraft to gratify these desires. ${ }^{53}$ Women are natural born liars, proud and vain, and their hearts are ruled by malice. ${ }^{54}$ And all of these defects made women the devil's ready dupes or willing slaves.

Institoris and Sprenger's misogynist arguments ought not to be taken for granted. Although such views were, no doubt, common in the late Middle Ages, nowhere else are they so forcefully linked to notions of witchcraft. No other fifteenth-century demonologist, not even a man such as Molitor, went much beyond Nider's brief enumeration of women's relevant weaknesses. Institoris and Sprenger, however, conceived of witchcraft as essentially rooted in and defined by women's sins, and as all but inconceivable without it.

Nonetheless, although their misogynist views are violent and striking, they occupy a relatively small part of Institoris and Sprenger's text, being for 
the most part confined to the single questio devoted to women and their natures. This chapter is also more straightforwardly a collection of classical and scriptural passages than is any other in the Malleus; on the subject of women, the authors' personal experience, so evident elsewhere, is notably absent. Neither is their pervasively misogynist argument entirely self-consistent, since, if all or most women were indeed so thoroughly evil, then all or most women should be prospective witches, and this is clearly not the case - only certain identifiable women are likely to be witches.

Although the Malleus represents women with a variety of shared, inherent weaknesses, and although these weaknesses created a propensity for a variety of sins, one weakness and one sin - carnality and lust, respectively were especially characteristic of witches. Women, Institoris and Sprenger observed, are more carnal than men, "as their many carnal depravities make clear." ${ }^{\prime 5}$ By this defect, woman are more enslaved to their desires and the lusts of the flesh, and are correspondingly less rational, spiritual, and intelligent than men. So closely are women and the sin of lust identified in the minds of the authors that they use the very word "woman" as a kind of metaphorical shorthand for lust. Institoris and Sprenger advise that whenever one reads censures of women, these "can be interpreted to mean bodily concupiscence, such that 'woman' is always understood to refer to the lusts of the flesh. ${ }^{~} 56$

From women's unsatisfied sexual desires sprang their unequaled malice: the most malicious of women were the most lustful; and the most lustful of women were witches, whose sexual appetite was insatiable, and who, "for the sake of quenching their lusts, excite themselves with devils. ${ }^{, 57}$ A witch's perverse sexuality was echoed in her magic: the sexual dysfunction caused by her spells, impeding procreation and legitimate sexual relations, revealed "that witchcraft arises more often from adulteresses, fornicatresses, etc. ${ }^{58}$ Other vices characterizing witches, notably infidelity and ambition, paled beside the witch's sexual demands. For this reason, the authors add, "those among ambitious women who burn more to satisfy their depraved lusts - as do adulteresses, fornicatresses, and the concubines of the great - are more infected."This was of enormous concern to Institoris and Sprenger, who worried that, through their magic, witches were gradually insinuating themselves into the highest ranks of European society. A witch in such a position had the power to poison her lover's mind, infecting him with a mad love that no shame or reason could gainsay,

which threatens both the extermination of the faith and intolerable daily danger, because witches know how to change their minds so that they will permit no harm to be done to them, either by their lovers themselves or by others. And so their numbers daily increase. ${ }^{59}$ 
In this way, in a few sentences, the authors transform the lust of women into witchcraft, and then into an apocalyptic vision of a world overrun with witches and sexual deviance.

The worthy inquisitors certainly did not invent the perverse sexuality of witches out of whole cloth; both heretics and night-traveling women were linked in masculine imagination with traditions of deviant sexuality. Indiscriminate and orgiastic couplings were a familiar topos in clerical descriptions of heretical cults, and Nicholas Jacquier was merely following this tradition when he claimed that

nearly all worshipers in the heresy and sect of witches or sorcerers' cults, many of whom, of both sexes, have revealed this willingly and by the sign of their blushes, assert that at their meeting which they hold for the worship of demons, they themselves, along with the demons which appear, are at times carnally pleasured in turn without measure so forcefully that it is brought about that many of them remain afterwards afflicted and debilitated for some days. ${ }^{60}$

But this was not at all the same kind of sexual sin as preyed upon the minds of Institoris and Sprenger; this was rather the deviant sexuality of the heretical cult. Both men and women alike, as Jacquier was careful to observe, participated in this filthiness, and their perverse lusts had no wider connotations: sexual sin is simply a generic characteristic of the heretic to Jacquier, and not a logically necessary part of a larger whole.

In the Malleus, however, witchcraft, femininity, and sexual sin form a tight constellation of interrelated ideas: unbridled feminine sexuality led to witchcraft, which expressed itself most typically in sexual, reproductive, or marital dysfunction; the defining act of the witch was sexual intercourse with the devil; men who committed adultery, whose lusts were unrestrained like a woman's, became liable to the spells of witches; and this feminine vice led directly to a second inversion of the natural order, because such men then allowed themselves to be dominated by women. To Institoris and Sprenger, witchcraft, adultery, and feminine domination lead logically to a coherent, closely interconnected conception of a wide-ranging occult conspiracy against society.

In an interesting passage, the authors ask rhetorically: what is the use of finding remedies for witchcraft when men are so sunk in depravity, and when

the landed magnates, prelates, and other rich men are most often involved with this wretchedness; indeed this is the time of women . . . since now the world is full of adultery, especially among the nobles - why should those who hate the remedies write about them? ? $^{61}$

Institoris and Sprenger believe themselves to be living in an age of adultery, an age of witchcraft - an age of women. The "wretchedness" referred to, which 
emasculates the great men of the world and makes them subject to their mistresses, may be either witchcraft or adultery, but it matters little, since in Institoris and Sprenger's minds sexual and diabolical sins are so closely identified. Thus, the relationship between sexual deviance and witchcraft was reciprocal: disordered sexual relationships engendered witches, and witchcraft, in turn, disordered sexual relationships. ${ }^{62}$

To Institoris and Sprenger, notions of "witches" and "witchcraft" served to reify, in the form of a wholly corrupt female body, the threats and the anxieties posed by human sexuality. Categorizing witches as embodiments of sinful female sexuality provided the authors with a useful means to control the unbridled sexuality of women that led to misfortune and disaster. ${ }^{63}$ As Guido Ruggiero puts it, witches were "sexual outsiders," whose activities, from the perspective of the dominant culture, threatened the natural order of society with the wrath of God. ${ }^{64}$ Faced with the possibility of another Sodom, Institoris and Sprenger defined witchcraft so as to localize the responsibility for sexual sin in the bodies of particular women, bodies which could be discovered, punished, and burned. Further, by the very act of categorization order was imposed: through the creation of an ordered semantic and intellectual system, Institoris and Sprenger provided the necessary terms for a satisfactory symbolic discussion of human sexuality, order, and power. In this new conceptual field, disordered sexuality is identified with the devil, inverted gender roles and sexual dysfunction with witchcraft, and defective social and political hierarchies with women and women's sins. None of this, however, is possible without the use of witches and witchcraft as an ordering term; witchcraft, as it were, provides the conceptual grid which binds this cognitive map together.

In theoretical terms, such a model makes considerable sense. If one accepts the fiction that women were controlled within an imposed sexual hierarchy, and that feminine power and influence within society were subsumed within a discourse of gender and sexuality, then any disordering manifestation of women's power, influence, or behavior must be understood in terms of sexual perversity. In other words, because men in late-medieval and earlymodern Europe tended to view women as sexual beings, existing within a rigidly defined sexual hierarchy, any perception of feminine deviance could logically be interpreted as a manifestation of sexual deviance. ${ }^{65}$ As soon as maleficium began to be seen as a particularly feminine crime, it became correspondingly necessary to view witchcraft within the rubric provided by sexual perversity. Such a construction seems even more probable if the village discourse of magic conceals a hidden discourse of women's power and of negotiated female social roles. The gendered aspects of Institoris and Sprenger's construction of witchcraft, I suggest, thus reflects their own experience of 
maleficium as principally a woman's crime, understood in terms of what they conceived "woman" to mean.

As a point of comparison, Stanley Brandes has described a very similar complex of ideas in his study of gender construction in modern Andalusia. ${ }^{66}$ In Andalusian society, gender boundaries are comparatively rigid, and women's behavior and social roles are quite restricted. Nonetheless, men feel themselves constantly under threat by the dangerous and potent forces under women's command. Much of this fear is specifically sexual, since Andalusian men fear the debilitating effects of an adult woman's sexual appetite, which "threatens in various ways to rob them of their masculinity and convert them symbolically into females. ${ }^{, 67}$ Women are insatiable, lustful seductresses, whose temptations men are all but powerless to resist. Women also command formidable and malign magical and supernatural powers, linked directly to their sexuality. Menstrual magic is especially potent, as is the magic of widowed, non-virginal, and/or sexually unsatisfied women. ${ }^{68}$ Men in this society constantly stress their own moral and social superiority over women - they equate themselves with God and women with the devil - yet they also fear the disordering sexual and magical powers of women. Both masculinity and social order are defined against a rigidly controlled, powerfully sexualized notion of femininity; anxiety about the stability of these structures expresses itself here, as in the Malleus, in terms of fears of occult harm and deviant sexuality.

On a more abstract level, this analysis parallels Bruce Kapferer's interpretation of Sinhalese concepts of the feminine and demonic. ${ }^{69}$ Kapferer suggests that Sinhalese women provide their culture with central mediating and articulating symbols precisely because their subordination to men is so central to their society. In his view,

Sinhalese women are vital symbols at once responsive to, and concentrating in their being, the forces and processes ordering and disordering the cultural and social universe of action and experience. ${ }^{70}$

The point is that if the social position of women in society is symbolically linked to a wider conceptual field (and in the late Middle Ages the cult of the Virgin alone would demonstrate that this was true), then perceived deviations from the approved norm carry correspondingly greater meaning and are of proportionally more concern, depending upon the breadth and centrality of women symbolically. Furthermore, the reverse is also true: just as perceived feminine deviance carries the threat of more general disorder, so misfortune and failure may be perceived to be the result of women's misbehavior. Thus Sinhalese women understand that, as women, their bodies pose a unique threat to ordered social hierarchies, and so "are culturally motivated to incorporate 
within themselves the misfortune and suffering that strikes at the household." ${ }^{\text {71 }}$ Lyndal Roper has similarly shown that political power and authority were conceived metaphorically in terms of the sexual dominance of husband over wife in post-Reformation Augsburg. ${ }^{72}$ For the urban patriarchate, women's sexual sins were acutely felt to be a threat to established structures of order, and "women's lusts were to be feared as unbridled and demonic."73

Taken as a kind of symbolic discourse, the construction of witchcraft and the constellation of related ideas that revolve around it in the Malleus are thus neither unique nor unreasonable. It is in this context, perhaps, that we should understand Institoris and Sprenger's otherwise risible fascination with the penis-stealing exploits of witches. It is doubtless true, as Mary O'Neil has suggested, that much of the evidence for this practice was found in a tradition of bawdy, rustic joking which the inquisitors lamentably misunderstood. ${ }^{74}$ But, while it may seem absurd to suggest that anyone could seriously believe that a witch could steal a man's penis and keep it alive and well in a bird's nest on a diet of oats, and that, when the owner finally came to retrieve his missing property, the witch would admonish him to put back the largest of those he found because it belonged to a secular priest, it is not absurd to suggest that, by so doing, the witch is only doing in a singularly literal way what she and her sisters were accustomed to do more figuratively: make a man into a woman. ${ }^{75}$

A similar conceptual move may explain why one of the most common forms of maleficium was to cause impotence. The fact that men were peculiarly susceptible to such magic suggests that masculine sexuality was itself fragile and easily disturbed: physically, witches could prevent erections and inhibit the flow of semen; psychologically, witches could cool the desire necessary for satisfactory sexual performance. ${ }^{76}$ When enchantments permitted a man to perform sexually only with a witch, he acquired a passive, "feminine" social role, a role that mirrored the witch's own sexual servitude to the devil.

Inversions of the sexual and social order were characteristic of witches in other ways as well. In another tale of symbolic emasculation and sexual inversion, Institoris and Sprenger relate that a well-born citizen of Speyer was cursed with an obstinate and evil-tempered wife, who, no matter how much he might try to please her, repaid him with recalcitrance and insults. One day when the man tried to escape his wife's incessant abuse, she dared him to strike her, saying that "unless he thrashed her, he had neither honesty nor honor left in him." "77 Goaded at last to violence by these "heavy words," the man slapped his wife lightly on the rear and at once toppled senseless to the floor. Thereafter he was confined to bed for many weeks. For this unfortunate, appropriately masculine behavior was the immediate cause of his bewitchment: while he patiently endured his wife's taunts, while he accepted a passive, "woman- 
ish" social role, his wife was content merely to abuse him. When, on the other hand, he finally dared to act like a man, he was struck down and left even more feminized: weak, bedridden, domesticated, and dependent.

Amid so much talk of passive, emasculated men, it is surprising that Institoris and Sprenger have so little to say on the subject of sodomy. ${ }^{78}$ Even their demons, like their witches, are primly heterosexual, and would never consider participating in a sexual act contra naturam. Of course, one perfectly plausible explanation for this omission is that Institoris and Sprenger are writing specifically about witches, whereas sodomy is a crime most often associated with men. In consequence, although it too, is closely associated with lust, inverted gender roles, and sexual perversion, it does not directly intrude upon the purely feminine world of witchcraft. On the other hand, we may also note the words with which Institoris and Sprenger conclude their diatribe against the female sex:

And blessed be the Most High, who up to the present has preserved from so vile a disgrace [as witchcraft] the male sex, in which He chose to be born and suffer for us, and therefore accorded it this privilege. ${ }^{79}$

These words unmistakably echo a phrase of William of Paris, who praised the Almighty in similar terms, but for quite different reasons: William thanked God that men, at least, had never been sodomized by fallen angels, although demons were theoretically quite capable of such an act. ${ }^{80}$

In the corresponding passage of the Malleus, on the other hand, witchcraft replaces sodomy as the "unthinkable" abomination for men. Here the authors do semantically precisely what Institoris did conceptually in his discussion of the young demoniac who could not be freed of his devil on account of "the Lombards" (that is, because of the sin of sodomy): "the worst vice of lust" is ignored in order to focus entirely upon the witch. ${ }^{81}$ Such odd substitutions demonstrate the similarities between the authors' conception of witchcraft and contemporary notions of sodomy: both are sexually disordering, both threaten masculine sexuality and gender identity, and for these reasons both are symbolically linked to a wider cognitive field. In each case, they are crimes uniquely offensive to God and to man; they are treason - lèse majesté - offenses "against divine order and against the commonwealth." ${ }^{82}$ Like the witch, the sodomite so offended God that his whole community was liable for his sin: plagues and natural disasters were only a foretaste of the apocalypse that could ensue from the wrath of an angry God, and for this reason aggressive persecution of the guilty was absolutely required. ${ }^{83}$ Institoris and Sprenger's description of witchcraft reminds one irresistibly of Jonathan Goldberg's description of sodomy in late-medieval and early-modern thought: "It names something unnamable, something that goes beyond the evidentiary and the 
logical; it is a category of violation and violates categories." ${ }^{84}$ Witchcraft could well be described in similar terms with this exception: in Institoris and Sprenger's mind witchcraft was not an "utterly confused" category, but a logical and eminently "thinkable" one. As a pervasive and central cultural symbol, witchcraft allowed the inquisitors to replace confused, difficult, and potentially dangerous concepts and relationships with ones that were more artificial, but for this reason also safer, more logical, and more readily controlled.

Throughout the Malleus, Institoris and Sprenger try to establish a reciprocally defining relationship between their construction of witchcraft and the persons of real individuals who might plausibly be suspected of such a crime. For this endeavor they created a very detailed image of the archetypal witch. She was a woman, certainly, but she was not just any woman - so inclusive an ascription would have made nonsense of the category the authors worked so hard to make sensible. Rather the witch of the Malleus was determined first by the parameters of the category which Institoris and Sprenger had constructed: more than anything else, a witch to them was a person with a reputation for possessing and using harmful occult powers. Yet Institoris and Sprenger were not satisfied to model their witch so straightforwardly upon popular perceptions of unwelcome sorcerers. The unmodified village magician provided them with no easy points of contact with the larger conceptual field of witchcraft as they understood it. True, any use of magic could be diabolized through the theory of the demonic pact, but there was a considerable difference in their minds between magic, even of the most diabolic stripe, and witchcraft. Much of this difficulty evaporated, however, as soon as the authors chose to emphasize the essentially feminine nature of witchcraft. With witches defined exclusively as women, a fortuitous homology was formed between them, night-flying strigae, and the women of the bonae res, traditions which formed the core of numerous alternative visions of witchcraft.

Yet the witch in the Malleus was also not simply a female sorcerer; she was also the personification of deviant or "bad" female sexuality. For all their misogyny, Institoris and Sprenger never accuse chaste virgins of witchcraft. Indeed, one of the most remarkably virtuous characters to be found in their text is a woman, a "poor little virgin and most devout," who was able to cure bewitched persons by merely reciting the Lord's Prayer with complete faith. ${ }^{85}$ Witches instead were adulteresses, murderous midwives, and evil mothers, women defined by the authors as personifications of feminine sexuality. The witch's relationship with the devil was not defined in terms of conventional notions of heretical cults, but through sexual relations: the witch did not worship the devil, she slept with him. The link thus established between female sexuality and physical harm of all sorts gave Institoris and Sprenger's concep- 
tion of witchcraft an explanatory power that rival conceptions lacked. Witchcraft provided a coherent system through which a whole constellation of socially disordering forces could be understood; it created a conceptual field in which anxieties about social order and material well-being could be arranged, understood, and, at least potentially resolved.

Notes

1 "Cur in sexu tamen fragili mulierum maior multitudo maleficarum reperitur quam inter viros, et quidem in contrarium in argumenta deducere non expedit." Malleus, pt. 1, qu. 6, p. 40.

2 See Robin Briggs, "Men against Women: The Gendering of Witchcraft," ch. 7 of Witches and Neighbors; E. William Monter, "The Pedestal and the Stake: Courtly Love and the Witchcraze," in R. Bridenthal and C. Koonz, eds., Becoming Visible (Boston: Houghton Mifflin, 1977), 130-4; Brian Levack, The Witch-Hunt in Early Modern Europe (London: Longman, 1987), 124.

3 Christina Larner, Enemies of God: The Witch-Hunt in Scotland (Baltimore: Johns Hopkins University Press, 1981), 100.

4 A concise summary of these explanations for a prescriptively gendered construction of witchcraft appears in Brauner, 13-27.

5 That witches were most usually women, the authors remark, "cum ipsa experientia preter verborum et fidedignorum testimonia talia facit credibilia." Malleus, pt. 1, qu. 6, p. 40. The point is important enough to bear repetition; a few pages later the authors again observe that "in these modern days this perfidy [witchcraft] is more commonly discovered among women than among men, as actual experience teaches" ("Sed quia adhuc modernis temporibus hec perfidia amplius in mulieribus quam in viris inuenitur vt ipsa experientia docet"). Ibid., 42.

6 See Brauner, 13; and, in a somewhat different context, Marianne Hester, "Patriarchal Reconstruction and Witch Hunting," in Jonathan Barry, Marianne Hester, and Gareth Roberts, eds., Witchcraft in Early Modern Europe (Cambridge: Cambridge University Press, 1996): 288-306. Contra Cohn, Europe's Inner Demons, 239-51.

7 Katharine Fischer Drew, trans., The Laws of the Salian Franks (Philadelphia: University of Pennsylvania Press, 1991), 64.3

8 "quia nimium habundant tales peruerse mulieres in delphinatu et in gaschonia." Spina, consid. 10.

9 "Sciendum est quod nedum mulieres uadunt ad ludum; sed etiam uiri, sed quia plures sunt mulieres uiris ideo de eis magis fit sermo." Visconti, c. v.

10 Jacquier, 41. Jacquier was refining an argument made earlier by Jean Vineti, an inquisitor at Carcassone, in his Tractatus contra Daemonum Invocatores (c. 1450), Hansen, Quellen, 125.

11 Errores Gazariorum, 279-81.

12 "Item, ex omni statu et condicione hominum dicunt de hac dampnabili secta esse." La Vauderye de Lyonois en brief, Hansen, Quellen, 188-95; 191.

13 Susanna Burghartz, "The Equation of Women and Witches: A Case Study of Witchcraft Trials in Lucerne and Lausanne in the Fifteenth and Sixteenth Centuries," in Brian Levack, ed., Articles on Witchcraft, Magic, and Demonology, 10 vols. (New York: Garland Publishing, 1992), 10 (Witchcraft, Women and Society): 67-83.

14 Burchard of Worms, Corrector, Patrologia Latina 140, 961-73.

15 Étienne de Bourbon, no. 371.

16 A.G. Little, ed., Liber Exemplorum ad Usam Praedicantium, in The British Society of Franciscan Studies 1 (1908), 153.

17 "Hec fuit quedam mulier que permisit mori juvenem amore ipsius. Cumque graviter 
infirmaretur, quibusdam sortilegiis ut se vindicaret de illa, mutavit illam in catellam, quod Deus permisit pro peccato suo.” Jacques de Vitry, no. 250.

18 "Huiusmodi autem vetule leve sunt inimice Christi et ministre diaboli atque hostes castitatis." Ibid., 251.

19 "Ipse quidem mulieres minus vigent in racione et intelligencia quam viri, et hinc est quod magis istis superstitionibus illaqueate tenentur et difficilius amoventur.” John of Frankfurt, Questio, utrum potestas cohercendi demones fieri possit per caracteres...., in Hansen, Quellen, 76.

20 "ex phantasiae et imaginativae virtutis debilitatione, cuius signum est quod vetulae et pueri et puellae et idiotae proniores sunt ad tales superstitiones credendas vel observandas;" Jean Gerson, Contra Superstitiosam Dierum Observantiam, in Oevres complètes no. 503; 7:120.

21 Nider, Praeceptorium, 1.11, bb. This passage would retain considerable currency, and was quoted virtually verbatim in the Malleus, pt. 1, ch. 6; See also Bernard Basin's, Tractatus de Artibus Magicis ac Magorum Maleficiis (1482; reprint, 1600: NP, Frankfurt), 16; and in Martin of Arles, 446.

22 "Unde ortum habuit illud de vetulit epitheton: vetulae sortilegae, gallice vieilles sorcières." Gerson, Contra Superstitiosam Dierum Observantiam, 120.

23 Jacques de Vitry, no. 262.

24 Burchard of Worms, De Erroribus, 974. For an account of a much later but remarkably similar practice, see Mary R. O’Neil, "Missing Footprints: Maleficium in Modena," Acta Ethnographica Hungarica 37 (1991/92): 123-42.

25 The Confessional of Egbert, 29, in McNeill and Gamer, 246. "Witchcraft" is given by the editors along with "druid-craft" for the Old English "dry-cræft."

26 Lea, Materials, 1:144.

27 Lea cites the provisions granted by Alfonso II of Aragon in 1176. Ibid., 139-40.

28 Cohn, Europe's Inner Demons, 150.

29 Yet Nider himself does not gender witches consistently, and his most fully described maleficus, the arch-witch Staedelin, is a man. It is likely, however, that here we glimpse a contradiction between Nider's own conception of witchcraft, and the beliefs and experiences of his informant, Peter Gruyères of Bern. See Blauert, 57-9.

30 J.A. Sharpe, "Witchcraft and Women in Seventeenth Century England: Some Northern Evidence," Continuity and Change 6 (1991): 179-99; 194. See also Sharpe, Witchcraft in Seventeenth Century Yorkshire: Accusations and Countermeasures, Bothwick Paper 81 (1992), 18; Briggs, Witches and Neighbors, 265-71.

31 Clive Holmes, "Women: Witnesses and Witches," Past and Present 140 (1993), 45-78; 51.

32 Christina Larner, Enemies of God, 88-90.

33 See David Nicholas, The Domestic Life of a Medieval City:Women, Children and the Family in Fourteenth-Century Ghent (Lincoln: University of Nebraska Press, 1985), 21.

34 Thus Ivo of Chartres wrote that on occasion God permitted the devil to prevent sexual intercourse through the actions of "female sorceresses and witches" ("Si per sortiarias atque maleficas, occulto sed nunquam injusto Dei judicio permittente et diabolo praeparante, concubitus non sequitur”). Panormia, c. 117, Patrologia Latina 161.

35 To give just one of many possible examples, Burchard condemns love magic done by weaving and ligatures as sins specifically characteristic of women, Corrector, Patrologia Latina 140, 961, 972.

36 "Non autem mulierculae illa faciunt sua naturali virtute aut rerum aliarum quarum utuntur ministerio; sed ministerio daemonum quorum utuntur pactis et sacramentis." Gabriel Biel, Supplementum in XXVIII Distinctiones Ultimas Quarti Senteniarum, dist. 34, q. 1, in Lea, Materials, 1:170.

37 See Scholz Williams; D.P. Walker, Spiritual and Demonic Magic (1958, reprint, Notre Dame: University of Notre Dame Press, 1975). The humanist scholar Giovanni Pico was 
the author of Adversus Astrologiam, among other things, and should not be confused with Gianfrancesco Pico, the author of the dialogue on witchcraft, Strix.

38 For a concise summary of these practices, see Kieckhefer, Magic in the Middle Ages.

39 Nider, Praeceptorium, 1.11, v.

40 Ibid., 1.11 , l, ee.

41 Martin of Arles, 367-75, 405-7.

42 Ibid., 385-6, 415.

43 Ibid., 362.

44 "quod daemones alliciuntur per varia genera lapidum, herbarum, lignorum, animalium, carminum, rituum ... His ergo rebus vtitur maleficus vel malefica instinctu daemonis per pactum inuocationis tacite vel expresse." Ibid., 416.

45 "vel ob desperationem, vel paupertatem, vel odia vicinorum, vel alias tentationes per Diabolum immissas, [quibus non resistunt] . . sese Diabolo deuouendo." Molitor, c. 10 , p. 714 .

46 "Diabolus per se, siue Magos seu Maleficos vera et futura praedicere alteri non potest." Ibid., 713-14.

47 An exception is Institoris and Sprenger's insistence that midwives were especially prone to witchcraft, and that midwife witches were the most powerful and most abominable of the breed. These women, they claim, "exceed all other witches in their villainy," and, worse still, were so numerous "that there is not the smallest hamlet where a witch of this kind may not be found" (Incidentaliter reducuntur et obstetrices malefice omnes alias maleficas in flagiciis excedentes . . quarum etiam tantus numerus vt ex earum confessionibus compertum est quod non estimatur villula vbi huiusmodi non reperiantur existit [sic]"). Ibid., pt. 3, qu. 34, p. 252. Despite the assurance of this ringing denunciation, the testimony of contemporary witch-theorists and the evidence of trials indicates that, in this case, the authors were wrong: midwives were neither widely identified with witches nor singled out for prosecution. See David Harley, "Historians as Demonologists: The Myth of the Midwife-Witch,” Social History of Medicine 3.1 (1990): 1-26; and Ritta Jo Horsley and Richard A. Horsley, "On the Trial of the 'Witches:' Wise Women, Midwives and the European Witch Hunts," in Marianne Burkhard and Edith Waldstein, eds., Women in German Yearbook 3 (Lanham, Maryland: University Press of Amherst, 1986): 1-28. Institoris and Sprenger's idiosyncratic and obsessive interest in midwife-witches may stem from the disproportionate weight they assign to the testimony of the single "repentant witch" of Breisach, whose confession - mentioned each time the subject of midwife-witches arises - provided the authors with what they considered unimpeachable expert testimony. Ibid., pt. 1, qu. 12, and pt. 2, qu. 1, chs. 2 and 13.

48 Malleus, pt. 1, qu. 6.

49 "in omnibus viribus tam anime quam corporis cum sint defectuose non mirum si plura maleficia in eos quos emulantur fieri procurant.” Ibid., 42.

50 Ibid., 42.

51 "Dicitur enim femina fe et minus quia semper minorem habet et seruat fidem." Ibid., 42. Where the authors came across this famous and thoroughly ridiculous stab at etymological learning is unknown.

52 "Quantum insuper defectum in memorativa potentia cum hoc fit in eis ex natura vitiium nolle regi sed suos sequi impetus sine quacunque pietate." Ibid., 43.

53 Ibid., 42-3.

54 Ibid., 44.

55 "Ratio naturalis est, quia plus carnalis viro existit vt patet in multis carnalibus spurcitiis." Ibid., 42.

56 "Unde vituperationes leguntur in concupiscentiam carnis interpretari possunt vt semper mulier per carnis concupiscentia intelligatur." Ibid., 41.

57 "Unde et cum demonibus causa explende libidinis se agitant." Ibid., 45.

58 "Secundo eadem veritas scilicet quod adultere fornicarie etc., amplius existunt malefice 
ostenditur per impedimentum maleficale super actum generatiue potentie.” Ibid., pt. 1, qu. 8, p. 52 .

59 "Et quibus etiam et exterminium fidei seu periculum intolerabile quotidie imminet quod eorum animos immutare taliter sciunt quod eis nullum siue per se siue ab aliis fieri permittant sicquod quotidie crescunt." Ibid., 45-6.

60 "Cum itaque fere omnes haereses et sectae maleficorum siue fascinariorum cultores, quorum plures ex eis, vtriusque sexus, hoc sponte et cum signis erubescentiae fateantur, asserant, quod in congregatione sua, quam faciunt ad cultum Daemonum, ipsi cum Daemonibus apparentibus, quandoque ad inuicem inordinate carnaliter voluptantur, adeo vehementer, vt praetactum est, quod plures ex eis inde postea per aliquot dies manent afflicti et debilitati." Jacquier claimed that this proved that the deeds of the witches were real, since everyone knew that "operations of Venus or the carnal passions cannot be completed or consummated by those sleeping" ("quia experientia manifeste docet, quod operationes Venereae et passiones carnalis voluptatis perfici siue consumari non possunt a dormientibus."). Jacquier, 37.

61 "Item ubi ... Optimates praelati et alii diuites sepissime his miseriis inuoluuntur. Et quidem hoc tempus muliebre ... cum iam mundus plenus sit adulterii praecipue in optimatibus, et quod opus scribere de remediis qui remedia abhorrent." Malleus, pt. 2, qu. 2, ch. 3, p. 164.

62 Innsbruck, the town overrun with abandoned women and witches is a case in point.

63 Institoris and Sprenger's attitude toward women and toward the disordering or emasculating powers of feminine forces is in this respect curiously similar to their near contemporary, Niccolo Machiavelli. See Hanna Fenichel Pitkin, Fortune is aWoman (Berkeley: University of California Press, 1984), 285-306 and passim.

64 Guido Ruggiero, The Boundaries of Eros (New York: Oxford University Press, 1985), 140.

65 See Sherry B. Ortner and Harriet Whitehead's introduction to Ortner and Whitehead, eds., Sexual Meanings: The Cultural Construction of Gender and Sexuality (Cambridge: Cambridge University Press, 1981): 1-27.

66 Stanley Brandes, "Like Wounded Stags: Male Sexual Ideology in an Andalusian Town," in Ortner and Whitehead, 216-39; see also James M. Taggart, Enchanted Maidens. Gender Relations in Spanish Folktales of Courtship and Marriage (Princeton: Princeton University Press, 1990).

67 Brandes, 224.

68 Taggart, 5.

69 Bruce Kapferer, A Celebration of Demons (Providence, Rhode Island: Berg Publishers and the Smithsonian Institution, 1991).

70 Ibid., 141.

71 Ibid., 150.

72 Lyndal Roper, The Holy Household (Oxford: Oxford University Press, 1989), 56-88.

73 Ibid., 131.

74 Mary R. O’Neil, “Tall Tales and Sober Truth: Storytellers before the Inquisition,” Æstel 3 (1995): 1-18.

75 See the Malleus, pt. 2, qu. 1, ch. 7; O’Neil, “Tall Tales," 8.

76 Malleus, pt. 1, qu. 8, p. 53.

77 “quod nisi eam verberaret nulla probitas aut honestas sibi inesset.” Ibid., pt. 1, qu. 18, p. 85.

78 They confine their remarks to the brief discussion of the devil's abhorrence for sodometrical sexuality and the reasons for his preference. See Chapter 3 above. For a recent discussion of the sin of sodomy in a medieval theological context, see Mark Jordan, The Invention of Sodomy in Christian Theology (Chicago: University of Chicago Press, 1997).

79 "Et benedictus altissimus qui virilem speciem a tanto flagitio vsque in praesens sic praeseruat in quo utique cum pro nobis nasci et pati voluit, ideo et ipsum priuilegiauit." Malleus, pt. 1, qu. 6, p. 45 .

80 "But blessed be the Most High, who has so preserved the male sex among people from 
their disgraceful acts up to this day, so that no man has been heard to have been polluted hitherto by that abominable lust" ("Benedictus autem altissimus, qui virilem speciem in hominibus a flagitiis eorum usque hodie sic servavit, ut nullus virorum ista nefaria libidine pollutus adhuc auditus sit”). William of Paris, 1071.

81 Malleus, pt. 2, qu. 1, ch. 10, pp. 127-8.

82 See Marc Boone, "State Power and Illicit Sexuality: The Persecution of Sodomy in Late Medieval Bruges," Journal of Medieval History 22 (1996): 135-53; 138.

83 Felix of Hemmerlin maintained that not only did the acts of sodomites "pollute the elements," but that so too did speaking and hearing of such crimes; such pollution was abhorrent as an offense against God, and because sodomy "generates pestilence and tempests." Felix of Hemmerlin, Tractatus de Exorcismis (c. 1455), printed in Malleus Maleficarum (Frankfurt: 1600), 2:418. See also Ruggiero, 109-13. Sodomy was also linked to notions of heresy: by the fifteenth century, throughout northern Europe, sodomites were called bougres, a word derived from "Bulgars" and associated with Manicheans in general.

84 Jonathan Goldberg, Sodometries (Stanford: Stanford University Press, 1992), 196.

85 "quadam virgine paupercula et ideo plurimum devota." Malleus, pt. 2, qu. 2, ch. 6, p. 171. 